\title{
Pemberdayaan Komunitas Remaja Dropout Sekolah Melalui Gerakan Sadar Literasi Islam Moderat Dalam Menangkal Paham Radikal Di Desa Tenggulun Solokuro Lamongan
}

\author{
Alimul Muniroh ${ }^{1}$, Arif Mansyuri ${ }^{2}$ \\ ${ }^{1}$ IAI Tarbiyatut Tholabah Lamongan \\ ${ }^{2}$ UIN Sunan Ampel Surabaya \\ alimulmuniroh1@gmail.com¹, mansyuri@uinsby.ac.id²
}

\begin{abstract}
This assistance was carried out in the village of Tenggulun Solokuro Lamongan which was the origin of the Bali bombing bombers I. Although the movement was not visible, the remnants of the jihadist ideology certainly could not just disappear from Tenggulun village. This assistance aims to strengthen literacy regarding moderate Islam in dropout youth from Tenggulun village so that they are fully aware of the importance of peaceful religious knowledge and also an affirmation of the teachings of moderation of Islam as a religion which is rahmatan lil 'alamin. From the mentoring process, the results show that moderate Islamic thinking is very useful for teens who want to learn peaceful Islam, while according to adolescents dropping out to study moderate Islam is tantamount to studying Islam that is rabmatan lil 'alamin.
\end{abstract}

Keywords: literacy, moderate Islam, teenagers, dropouts

\section{Pendahuluan}

Salah satu problem sosial mendasar yang dialami oleh masyarakat kita adalah sulitnya menerima perbedaan pandangan walaupun berasal dari sesama muslim. Bahkan sikap ekslusif ini diikuti oleh penolakan-penolakan kepada kelompok lain yang dianggap bukan dari kelompoknya. Pada gilirannya sikap tersebut melahirkan gerakan-gerakan radikal yang mengatasnamakan agama, terjadinya kekerasan yang mengatasnmakan agama/Tuhan.

Perlu diingat, pada tanggal 12 Oktober 2002, di Paddy's Pub dan Sari Club (SC) di Jalan Legian, Kuta, Bali telah terjadi peristiwa pengeboman yang menewaskan ratusan orang khususnya para turis yang berasal dari mancanegara. Peristiwa ini dikenal dengan perstiwa bom Bali I, karena setelah peristiwa itu serentetan peristiwa pengeboman juga terjadi lagi. Dari peristiwa bom bali tersebut, telah ditangkap pelaku pengeboman yang ternyata berasal dari Desa Tenggulun Kecamatan Solokuro Lamongan.

Desa Tenggulun merupakan desa yang cukup pelosok di kebupaten Lamongan. Secara umum masyarakat desa Tenggulun ini bercocoktanam, namun sebagaian yang lain menjadi buruh migran khususnya di negeri jiran. Pergesekan dengan kelompok luar inilah yang memungkingkan di desa Tenggulun ini mengenal gerakan-gerakan radikal Islam, di samping karena secara 
geografis karena jauh dari pusat keramaian yang menyebabkan desa Tenggulun ini menjadi tempat strategis gerakan Islam radikal.

Gerakan radikal yang berujung pada kekerasan terhadap orang lain memang perlu diwaspadai, apalagi bila gerakan tersebut lahir dari sentimen ajaran-ajaran agama. Namun demikian saat ini di Desa Tenggulun, sesungguhnya problematika bukan hanya masih adanya akar faham gerakan radikal namun juga masih banyak anak putus sekolah (dropout) yang perlu mendapatkan perhatian baik dari kalangan pemerintah atau masyarakat sosial yang luas.

Mengapa para remaja dropout ini perlu mendapatkan perhatian yang lebih. Setidaknya ada tiga hal yang melatarbelakangi pentingnya memperhatikan para remaja ini, Pertama para remaja dropout sesungguhnya adalah generasi penerus bangsa yang masih memiliki minat dan bakat namun karena berbagai macam situasi menyebabkan mereka tidak melanjutkan pendidikannya di tingkat lebih tinggi. Kedua, remaja dropout yang minim pengetahuan sangat rentan terjebak dalam kegiatan-kegiatan negatif, seperti tawuran antar remaja, menyerang kelompok lain, minumminuman keras, penyalah gunaan narkoba, pencuriandan lain-lain. Ketiga, dalam konteks remaja dropout di desa Tenggulun, para remaja dropout tersebut sangat rentan terjebak mengikuti gerakangerakan radikalisme.

Oleh karena itu, pendampingan ini memiliki tujuan untuk mendorong para remaja dropout di desa Tenggulun untuk terlibat dalam kegiatan positif di lingkungannya, dan memberikan penguatan kesadaran atas adanya Islam moderat, sehingga mereka tidak terjebak dalam kegiatankegiatan radikal. Ada banyak penyebab mengapa remaja mengalami dropout dari sekolah mereka. Diantaranya adalah faktor sosial ekonomi yang rendah dan faktor sosialbudaya yang kurang baik.Bila dibreakdown faktor tersebut meliputi faktor kawin usia muda, latar belakang pendidikan orang tua, lingkungan pergaulan dan rendahnya apresiasi masyarakat sekitar pada dunia pendidikan. Secara psikologis, dropout dari sekolah dapat terjadi karena minimnya motivasi dan tidak adanya engagement pada seorang anak. ${ }^{1}$

Di desa Tenggulun, saat ini ada sekitar 20 anak yang mengalami dropout dari sekolah. Mereka dropout dari berbagai macam sekolah, baik sekolah dasar, menengah ataupun lanjutan. Meskipun demikian, tidak semua masyarakat di desa Tenggulun kurang beruntung di dunia pendidikan, karena ada beberapa orang yang sudah berhasil lulus S-2 dan kemudian menjadi dosen di perguruan tinggi di sekitar desa, bahkan ada yang sudah lulus S-3. Dari sini sesungguhnya memunculkan adanya disparitas pendidikan pada masyarakat desa Tenggulun.

Dari sisi mata pencaharian, mayoritas masyarakat desa Tenggulun mayoritas bercocok

${ }^{1}$ Bridgeland, J., DiIulio, J., \& Burke Morison, K. (2006). The Silent epidemic : Perspectives of high school dropouts. Diakses 13 Desember 2011 (http://www.civicenterprises.net/pdfs/thesilentepidemic3-06.pdf). 
tanam. Namun sebagaimana masyarakat desa di Kecamatan Solokuro, masyarakat desa Tenggulun banyak yang merantau mencari nafkah ke negeri jiran, Malaysia. Tradisi buruh migran ini sudah turun temurun dilakukan bahkan ada beberapa penduduk asli desa Tenggulun kecamatan Solokuro yang mendapatkan Identity Card (IC) untuk bekerja secara permanen karena sudah tinggal di Malaysia sebelum tahun $1990^{2}$.

Desa Tenggulun berada di kecamatan Solokuro, kabupaten Lamongan yang diapit oleh desa Payaman, Tebluru dan desa Prijek. Nama DesaTenggulun menjadi sangat terkenal bahkan di seluruh dunia, karena ditangkapnya Amrozi dan saudaranya, warga desa Tenggulun, sebagai tersangka bom Bali I yang terjadi pada tanggal 12 Oktober 2002. Kondisi tanah di desa Tenggulun dapat dikatakan cukup subur meskipun untuk pertanian kebanyakan para petani mengandalkan curah hujan. Para petani di desa Tenggulun dapat menanam berbagai jenis tanaman seperti padi, jagung, kacang, mentimun, lombok dan lain-lain. Hasil tanaman utama di desa ini adalah padi dan jagung.

Masyakat desa Tenggulun, sebagaimana diungkapkan di atas, tidak hanya bercocok tanam namun juga menjadi buruh migran di negeri Malaysia. Tradisi menjadi buruh migran ini memang sudah lama ada di masyarakat kecamatan Solokuro. Mereka mencari nafkah sampai keluar negeri karena pada musim tertentu khususnya musim kemarau, air sulit dicari sehingga penghasilan petani dapat berkurang. Fenomena menjadi buruh migran ini sudah sejak lama ada. Sekitar tahun 1970an sudah banyak masyarakat yang merantau ke Malaysia. Mereka meninggalkan keluarga demi memperoleh penghidupan ekonomi yang lebih baik.

Bila dipandang secara sekilas kehidupan warga di desaTenggulun saat ini, tampak rumahrumah warga yang terdiri dari bangunan batu (tembok). Sudah jarang rumah-rumah yang terbuat dari kayu. Hal itu menandakan bahwa kehidupan ekonomi warga desa sudah mulai membaik. Namun demikian, bila ditelusuri lebih jauh, tak jarangr umah-rumah yang cukup bagus itu tak ada orangnya, karena ditinggal oleh penghuninya untuk merantau ke Malaysia. Kehidupan merantau ini, menyebabkan perpisahan keluarga, orang tua dengan anak, istri dengan suami adalah hal yang biasa dan wajar. Perpisahan itu kadang terjadi cukup lama. Bahkan tak jarang seorang ayah baru melihat anaknya setelah belasan tahun tidak bertemu. Jadi ayah baru melihat anaknya setelah si anak beranjak remaja.

Fenomena tersebut menyebabkan adanya kurang control dalam keluarga karena terkadang

2Sejak April tahun 1990 Pemerintah Malaysia menerbitkan kartu penduduk baru bagi warganegaranya, yang mewajibkan seluruh penduduk Malaysia untuk memilikinya. Lihat di https://dailyrakyat.com/kad-pengenalansejarah-dan-evolusi-memacu-kepintarannya/987, diakses pada 29 September 2018. Para buruh migran khususnya dari desa Tenggulun juga terkena dampak kebijakan ini. Namun para buruh migran yang telah tinggal lama di Malaysia berhasil mendapatkan identitas khusus dari pemerintah Malaysia. 
orang tidak bias mengawasi secara langsung pada anaknya karena anak-anak dititipkan kesanak saudara. Hal ini tentu saja sangat berpotensi anak remaja yang kurang memperhatikan pendidikan mereka karena adanya kurang control tersebut. Di sisi lain, pergaulan remaja saat ini, tidak hanya di kota namun sudah merambah kepelosok desa, sungguh menyedihkan. Banyak remaja yang suka hura-hura, tawuran bahkan sudah terjebak pada penyalahgunaan narkoba. Hal ini tentu adalah fenomena yang menyedihkan sehingga membutuhkan penanganan khusus.

Kondisi subjek dampingan remaja dropout di desa Tenggulun, Kecamatan Solokuro, Kabupaten Lamongan adalah sebagai berikut.

1. Remaja dropout di desa Tenggulun disebabkan oleh hal bermacam-macam, seperti minimnya ekonomi, kurangnya minat menempuh pendidikan dari remaja, minimnya dorongan untuk menyelesaikan pendidikan baikdari orang tua atau lingkungan sekitar.

2. Kondisi masyarakat desa Tenggulun yang banyak menjadi buruh migran di luar negeri membuat control terhadap remaja dari keluarga, sangat kurang. Meskipun tinggal di desa, pergaulan remaja sangat rentan terjebak pada kegiatan negative seperti tawuran atau penyalahgunaan narkoba.

3. Kurangnya kontrol terhadap remajadropout di desa Tenggulun dapat menjadikan mereka terlibat secara tidak sadar dengan gerakan-gerakan radikal yang memang masih rentan berkembang di desa atau tingkat kecamatan lainnya

Kondisi pedesaan yang membuat akses para remaja cukup terbatas. Namun adanya teknologi informasi sebenarnya dapat dimanfaatkan oleh para remaja putus sekolah tersebut untuk berkomunikasi atau memanfatkannya dengan kegiatan positif lainnya dengan lingkungan luar. Pendampingan remaja dilakukan supaya remaja tetap mempunyai pengetahuan dan keinginan belajar termasuk mempelajari Islam moderat walaupun telah dropoutdari sekolah

\section{Metode}

\section{Strategi yang digunakan}

Kegiatan pemberdayaan ini menggunakan pendekatan Participatory Action Research (PAR). Siklus PAR dimulai dari identifikasi masalah, perencanaan aksi, aksi dan evaluasirefleksi. Proses pemberdayaan masyarakat ini dengan melibatkan para stakeholders termasuk remaja dropout mulai dari proses, aksi, hingga evaluasi dengan langkah-langkah pemberdayaan sebagai berikut:

\section{a. Identifikasi Masalah}

Kegiatan ini diawali dengan adanya proses observasi awal untuk mengetahui kondisi secara umum pemuda desa Tenggulun kecamatan Solokuro Kabupaten Lamongan. Hasil 
identifikasi melahirkan data awal pengabdian. Proses ini hanya melibatkan peneliti dan subjek partisipan kunci. Dari proses tersebut diperoleh perencanaan aktivitas-aktivitas yang hendak dilakukan secara bersama-sama. Para remaja dropout juga bersedia mengajak teman-teman mereka yang lain. Adanya identifikasi masalah dilanjutkan proses inkulturasi, yaitu pendamping masuk ke komunitas remaja dropout dengan mengikuti dan menyesuaikan aktifitas mereka, baik secara personal maupun secara komunal. Proses ini dimaksudkan agar tercipta hubungan yang baik dan saling percaya antara pendamping dan komunitas.

\section{b. Perencanaan Aksi}

Langkah berikutnya adalah perencanaan aksi. Pada fase ini dilakukan bersama-sama seluruh anggota remaja dropout desaTenggulun Kecamatan Solokuro Kabupaten Lamongan bersedia mengikuti proses pendampingan. Masing-masing individu diajak secara terbuka untuk memaparkan keinginan diharapkan. Namun demikian pada perencanaan aksi dipilih prioritas yang bisa dilakukan sebagai perwujudan dari tujuan pendampingan

\section{c. Melakukan Aksi}

Fase melakukan aksi merupakan implementasi dari perencanaan aksi yang telah disusun bersama dengan remaja dropout yang ada di desa Tenggulun Kecamatan Solokuro Kabupaten Lamongan. Dalam fase ini para remaja remaja dropout diajak untuk diskusi dan sharing permasalahan tentang perilaku positif sesuai dengan nilai-nilai ajaran Islam. Para remaja dropout juga dikenalkan dengan berbagai macam aliran dan gerakan Islam di Indonesia. Selain itu mereka diajak untuk berdiskusi tentang pentingnya menjaga perdamaian di dunia berlandaskan ajaran-ajaran Islam.

\section{d. Evaluasi-refleksi}

Evaluasi dilakukan melalui evaluasi proses dan hasil. Evaluasi proses dilaksanakan pada tiap-tiap langkah pendampingan. Hal ini untuk mengetahui sejauh mana proses tersebut sudah berlangsung sebagaimana yang diharapkan. Sementara evaluasi hasil merupakan evaluasi yang dilaksanakan di akhir pendampingan untuk mengetahui sejauh mana program tersebut memiliki dampak langsung terhadap persoalan-persoalan yang dihadapi oleh remaja dropout yang ada di desaTenggulun Kecamatan Solokuro Kabupaten Lamongan, serta untuk mengetahui sejauh mana pendampingan ini melahirkan cara berfikir, bersikap, maupun berperilaku anggota remaja dropout. Adapun refleksi adalah upaya untuk mengembil manfaat atas aksi dan evaluasi yang telah dilakukan. Refleksi berguna untuk menentukan kegiatan atau aksi pada tahap berikutnya. 


\section{Penulisan Laporan}

Penulisan laporana dalah proses terakhir setelah dilakukan evaluasi. Pada kegiatan ini, ditulis secara mendalam proses pendampingan yang telah dilakukan.dalam proses penulisan laporan, pendamping memaparkan latar belakang hingga hasil pendampingan.

\section{Hasil dan Diskusi}

Kegiatan pendampingan Islam moderat bagi remaja dropout di desa Tenggulun Solokuro Lamongan dilakukan dengan melibatkan beberapa remaja dropout. Kegiatan tersebut dilaksanakan di rumah salah satu remaja dropout dan seterusnya berpindah ketempat lain. Adapun hasil dari kegiatan pendampingan remaja dropout sekolah di desa Tenggulun Solokuro Lamongan adalah sebagai berikut.

\section{Remaja dropout di desa Tenggulun menyadari bahwa kita dalam kehidupan terdapat} berbagai macam perbedaan.

Melalui proses diskusi yang panjang, remaja dropout di desa Tenggulun menyadari bahwa masyarakat tidak hanya terdiri dari satu kelompok, melainkan berbagai macam kelompok dan aliran dapat berkembang di masyarakat. Di desa Tenggulun sendiri selain Nahdlatul Ulama dan Muhammadiyah, sebagai organisasi keagamaan mainstream, juga terdapat kelompok yang berafiliasi pada organisasi Jama'ah Islamiyah. Sebagai penduduk yang hidup di bawah Negara Kesatuan Republik Indenonesia, maka seluruh kelompok harus hidup saling bahu-membahu, bekerjasama untuk membangun desa Tenggulun. Kesadaran bahwa adanya kelompok yang plural dalam masyarakat merupakan suatu fenomena sosial alami. Perbedaan-pebedaan tersebut bukan merupakan persoalan dalam Islam. Perbedaan sudah ada dalam Islam bahkan sejak zaman Rasulullah. Pada saat itu Rasulullah merupakan hakam, pemberi kata putus dalam setiap perbedaan pendapat ${ }^{3}$.

\section{Remaja dropout di desa Tenggulun menyadari bahwa perdamaian dalam kehidupan} sangat diperlukan untuk menjaga keberlangsungan umat manusia.

Remaja dropout di desa Tenggulun berpendapat bahwa kehidupan yang damai lebih baik daripada kehidupan yang tidak tentram. Sesungguhnya dari awal penciptaannya, Islam mengajarkan perdamaian kepada umat manusia. Islam adalah agama rahmatan lil 'alamin, sehingga siapapun yang berada di sekitar kaum muslim seharusnya merasa terlindungi bukan merasa

${ }^{3} \mathrm{M}$ Kholid Syeirazi, Toleransi Beragama: Perbedaan itu Rahmat. http://www.nu.or.id/post/read/69734/toleransi-beragama-perbedaan-itu-rahmat, diakses pada 29 September 2018. 
terteror. Berbagai kelompok organisasi agama di Desa Tenggulun meskipun berbeda memiliki tradisi yang sama dalam kehidupan bermasyarakat. Misalnya ada tradisi mbendet, yaitu mencari ikan bersama-sama seluruh desa pada hari tertentu merupakan salah satu cara untuk menjalin perdamaian bagi seluruh penduduk desa Tenggulun. Kegiatan sosial kemasyarakatan yang dilaksanakan bersama oleh penduduk desa tanpa memandang aliran atau organisasi sosial keagamaan dapat mendorong adanya kebersamaan dalam masyarakat. Para remaja dropout sangat menyadari bahwa adanya kegiatan ini membuat mereka dapat berbaur dengan siapapun di lingkungannya, berkomunikasi dan berinteraksi sosial secara sehingga tercipta hubungan yang harmonis sesama masyarakat.

\section{Remaja dropout di desa Tenggulun menyadari pentingnya pemahaman Islam modeart agar tidak terpengaruh gerakan radikal.}

Remaja dropout di desa Tenggulun menyadari akan pentingnya ajaran Islam yang toleran bagi seluruh umat manusia. Bahwa ajaran-ajaran yang mengajarkan jihad masih ada di desa Tenggulun, itu adalah keyakin kelompok kecil yang memang dapat berdamai ketika hidup di desa Tenggulun. Namun demikian secara perlahan ajaran-ajaran berjihad, memerangi orang asing atau non muslim, dapat dilokalisir meski juga dihargai sebagai bagian dari pemahaman terhadap Islam. Pemahaman bahwa Islam itu agama yang damai lebih penting daripada mengedepankan kepentingan kelompok, yang kadang-kadang dapat merusak persahabatan dan perdamaian.

Para pemuda dropout diajak berdiskusi tentang ayat QS. al-Shûrâ: 15, yang memberi pemahaman bahwa ada hal-hal yang terkait dengan pluralitas kepercayaan yang harus dijaga. Ayat tersebut memberi pemahaman terhadap para remaja dropout bahwa Umat Islam memang harus menghargai keragaman kepercayaan, namun mereka harus tetap melaksanakan tugas dakwah, dengan cara yang bijak; Umat Islam harus tetap teguh dalam keimanan, sementara dalam urusan keduniaan boleh leluasa dengan agama lain selagi tidak keluar dari koridor sharî‘ah, tetapi dalam urusan akidah, satu sentipun umat Islam tidak boleh bergeser dari rel seharusnya; Umat Islam harus senantiasa berlaku adil, sekalipun terhadap kelompok yang berseberangan dalam akidah; Umat Islam harus menghargai kebebasan umat yang lain dalam menjalankan keyakinan (selama tidak mengganggu ketertiban dan keamanan bersama); dan terkait dengan prinsip keyakinan, umat Islam harus menghindari pertengkaran dengan umat yang lain kecuali dengan cara diskusi (mujâdalab) yang baik ${ }^{4}$.

\footnotetext{
${ }^{4}$ Lujeng Lutfiyah, dkk. "Deradikalisasi Pemahaman Alquran: Pendampingan Masyarakat Rawan Terpengaruh Gerakan Islam Garis Keras”. Mutawâtir: Jurnal Keilmuan Tafsir Hadis. Volume 6, Nomor 1, Juni 2016. Hal 85-112.
} 
4. Remaja dropout di desa Tenggulun memiliki kesadaran untuk bekerja mencari kehidupan yang lebih baik dengan merantau ke Malaysia, Papua, Flores dan juga ke Kalimantan daripada mereka terlibat kasus tawuran saat menonton hiburan "orkes dangdutan” yangberujung di penjara.

Remaja dropout di desa Tenggulun selain mengisi kegiatan mereka dengan berdiskusi tentang Islam moderat, juga mulai memikirkan masa depan mereka. Kehidupan pedesaan yang memiliki keterbatasan aset dan akses, membuat mereka berfikir untuk mengikuti jejak keluarga atau tetangga untuk menjadi buruh migran. Pilihan ini tentu saja merupakan pilihan terbaik bagi remaja dropout di desa Tenggulun, karena bagaimanapun juga mereka pada akhirnya harus bersikap realistik terhadap keberlangsungan kehidupan mereka sendiri. Namun demikian pemikiran-pemikiran tentang Islam moderat diharapkan masih tetap menjadi landasan berfikir dan berperilaku mereka dalam kehidupan sehari-hari dimanapun mereka berada, sehingga perilaku radikalisme dapat dicegah melalui diri mereka.

\section{Kesimpulan}

Setiap kegiatan pendampingan diharapkan memiliki hasil positif pasca pendampingan, meskipun untuk meraih hasil tersebut, tak jarang seorang pemberdaya harus melawati perjalanan yang berliku. Dari hasil pendampingan ini dapat ditarik kesimpulan sebagai berikut:\

1. Ajaran Islam moderat diterima oleh siapapun yang ingin mempelajari perdamaian. Remaja dropout di desa Tenggulun menunjukkan bahwa pemikiran tentang Islam moderat ini penting untuk diamalkan agar mereka dapat hidup damai berdampingan dengan komunitas yang berbeda. Bahkan di desa Tenggulun yang telah melahirkan para bomber, remaja dropout masih memiliki harapan agar kejadian serupa tidak terulang di negara Indonesia. Perdamaian yang dicita-citakan oleh para remaja dropout tersebut diilhami dari berbagai macam sorotan miring terhadap desa mereka ataupun karena mereka memang menginginkan kehidupan yang lebih damai.

2. Para remaja dropout di desa tenggulun senantiasa memiliki harapan untuk berubah. Lingkungan pedesaan yang jauh dari akses tidak menghalangi komunikasi bagi para remaja dropout untuk memiliki cita-cita yang lebih baik. Meskipun dalam hal pendidikan mereka kurang beruntung, namun keinginan untuk merubah nasib agar lebih sejahtera senantiasa terpatri dalam benak para remaja dropout tersebut. 


\section{Daftar Pustaka}

'Imârah, Muhammad. Perang Terminologi Islam Versus Barat.

Terj: Musthalah Maufur. Jakarta: Logos, 1989.

Alûsî (al), Mahmûd. Rûhal-Ma ânî. Beirut: Dâr al-Kutub al-'Ilmîyah, 1994.

Amal,Taufik Adnan. "Fazlur Rahman dan Usaha-Usaha Neo-Modernisme Islam Dewasa ini" dalam Fazlur Rahman. Metodedan Alternatif Neo-Modernisme Islam. Peny. Taufik Adnan Amal.Bandung: Mizan, 1994.

Anwar, M. Syafi'i. "kata pengantar" dalam Islamku, Islam Anda, Islam Kita. Jakarta: Wahid Insitut, 2006.

Bridgeland, J., DiIulio, J., \& Burke Morison, K. (2006). The Silent epidemic : Perspectives of high school $\begin{array}{llll}\text { dropouts. } & \text { Diakses } & 13 & \text { Desember }\end{array}$ (http://www.civicenterprises.net/pdfs/thesilentepidemic3-06.pdf).

Engineer,Asghar Ali. Islam dan Teologi Pembebasan. Terj. Agung Prihantoro. Yogyakarta: Pustaka Pelajar, 1999.

Fadl, Khaled Abou. Selamatkan Islam dari Muslim Puritan. Terj. Helmi Mustofa. Jakarta: Serambi Ilmu Semesta, 2006.

Https://Dailyrakyat.Com/Kad-Pengenalan-Sejarah-Dan-Evolusi-Memacu-Kepintarannya/987, diakses pada 29 September 2018.

Juergensmeyer,Marx. Teror Atas Nama Tuban: Kebangkitan Globalkekerasan Agama. Jakarta: Nizam Press \& Anima Publishing,2002.

Kartini, Kartono. Patologi Sosial. Jakarta: Rajawali Pers, 2004.

Lawrence, Bruce. Defenders of God: The Fundamentalist Revolt Against The Modern Age. New York: I.B. Tauris, 1990.

Lutfiyah, Lujeng. Ahmad Badrut Tamam, dan Alimul Muniroh. "Deradikalisasi Pemahaman Alquran: Pendampingan Masyarakat Rawan Terpengaruh Gerakan Islam Garis Keras". Mutawatir: Jurnal Keilmuan Tafsir Hadis. Volume 6, Nomor 1, Juni 2016. Hal 85-112.

Syeirazi, M Kholid. Toleransi Beragama: Perbedaan itu Rahmat, http://www.nu.or.id/post/read/69734/toleransi-beragama-perbedaan-itu-rahmat, diakses pada 29 September 2018.

Tim Penerjemah Alquran. Alquran dan Terjemahnya. Jakarta: Departemen Agama, 1971.

Thoha, Anis Malik. Tren Pluralisme Agama. Jakarta: Perspektif, 2005. Ya'qub, Mustafa Ali. "Radikalisme dan Metode Memahami Teks Agama", dipresentasikan pada Seminar Nasional Islam dan Terorisme. 2006. 